\title{
Multikultur dan Multiperspektif dalam HAM Internasional
}

\author{
Zeffry Alkatiri
}

\begin{abstract}
This paper discusses the problem of human rights in an international context in which it often causes conflict of interests among different nations. It turns out that the Human Rights Declaration does not always provide convenient guide to problem of human rights abuse. This paper aims at demonstrating differing views in the international discourse on human rights and the necessity to understand those differing views and issues related to human rights. This is crucial to avoid taking side unwisely.
\end{abstract}

KEYWORDS Human rights, International Human Rights, Human Rights Declaration.

Hak Asasi Manusia (HAM) adalah seperangkat hak dasar yang dimiliki setiap manusia secara alamiah sejak lahir untuk memenuhi kebutuhan hidupnya. Pengakuan HAM secara internasional meliputi hak kebebasan sipil, hak kebebasan politis, hak kebebasan dari penindasan, hak kebebasan dari penahanan tanpa melalui pengadilan, hak perlindungan sebagai individu yang mempunyai hak alamiahnya yang tidak dapat digugat, dan direbut oleh siapa pun atau dari pihak mana pun (Donnelly 1989: 2-4; Geoffrey 2002: 335-343; Nickel 1996: 18-21).

Pihak lain mengemukakan bahwa HAM merupakan sesuatu yang mutlak perlu bagi perkembangan individu. HAM merupakan sesuatu yang melekat pada semua orang setiap saat, hak yang tidak dapat dibeli ataupun diciptakan, hak yang dimiliki karena semata-mata sebagai manusia yang bermartabat, antara lain hak hidup dan hak kebebasan sehingga harus mendapat perlindungan mutlak (Davidson 1993: 1 -7; Over 1999: 2-3).

Atas dasar itu, HAM menjadi suatu konstruksi sosial yang dibangun dari kesadaran bahwa kedudukan manusia sebagai makhluk yang bebas dan berakal harus dijamin oleh negara dan beberapa haknya tidak dapat diganggu gugat (Urlich 2001: 214-215; Kleden 2000: xxv).

Pandangan konstruktivis tentang HAM menganggap bahwa HAM merupakan gejala sosial yang dibangun oleh manusia berdasarkan konsepsi moral untuk mendorong visi kemanusiaannya. Gejala sosial itu dijembatani oleh hak dasar yang sudah ada menyertainya. Undang-Undang HAM dan konstitusi lainnya juga merupakan implementasi dari teori konstruktivis tentang HAM. Termasuk dalam kategori itu adalah konsensus internasional tentang HAM yang menjadi fakta dan konstruksi sosial yang berpengaruh 
politis dan dapat dijadikan pembenaran umum untuk mengoreksi pelaksanaan HAM. Di satu sisi pengertian hak dapat menyatukan, di sisi lain dapat memecah belah suatu masyarakat. Hal itu disebabkan oleh perbedaan interpretasi (Donelly 1989: 23, 93; Urlich 2001: 214-215).

HAM pada dasarnya menjadi suatu konsep pengakuan atas hakikat dan martabat manusia yang dimiliki secara alamiah dan melihat tanpa perbedaan. Diyakini bahwa semua manusia dilahirkan merdeka dan setara dalam martabat mereka. Dalam konteks sosiologis, hubungan manusia dengan sesamanya dijembatani oleh hak yang dibatasi untuk menghormati hak orang lain. Konsepsi HAM membuat perbedaan status, seperti ras, agama, gender tidak relevan secara politis, secara hukum, dan menuntut adanya perlakuan yang sama tanpa memandang status serta kedudukan. Berdasarkan uraian di atas dapat dikatakan bahwa konsepsi HAM dapat bermula dari kesadaran akan martabat kemanusiaan, kesadaran akan kebutuhan dasar manusia, dan kesadaran terhadap moral kemanusiaan (Howard 2001: 1).

\section{Sejarah DUHAM}

Pada abad XVII mulai dikedepankan kemerdekaan dan kebebasan individu sebagai reaksi terhadap teokrasi-otokrasi yang mendorong revolusi Amerika dan Prancis. Pada abad XIX mulai ditekankan aspek kesetaraan di depan hukum yang menempatkan individu sebagai makhluk sosial yang perlu mendapatkan jaminan hukum. Dalam tahap itu hak sebagai individu diberikan kepada masyarakat. Pada abad XX kedua hak itu menjadi satu kesatuan sebagai hak dasar yang kemudian dicatat dalam Deklarasi Universal Hak Asasi Manusia (DUHAM) (Effendi 1994: 16; Crawshaw 2001: 3-5).

Masalah hak dan kebebasan telah dimasukkan ke dalam Deklarasi Kemerdekaan dan Konstitusi Amerika (1776-1789), Konstitusi Polandia (1789), dan Deklarasi Kemerdekaan Prancis (1789). Intinya menekankan bahwa manusia mempunyai hak kebebasan dan hak yang sama di depan hukum. Hak yang dimiliki sejak lahir tidak dapat dirampas oleh kekuasaan negara sekalipun. Dalam deklarasi itu hak keberadaan manusia dihubungkan dengan hak keberadaan masyarakat dan negara. Deklarasi itu merupakan suatu perjanjian hukum (kontrak sosial) yang memperlihatkan kesetaraan antara hak dan kewajiban individu, masyarakat, dan negara dalam konteks masyarakat kulit putih Amerika Serikat dan Prancis. Dokumen itu kemudian menjadi landasan bagi munculnya Konstitusi Prancis (1791) dengan tambahan hak ekonomi dan sosial. Namun, dokumen deklarasi itu belum mencakup permasalahan perbudakan dan kerja paksa pada masyarakat di luar komunitas kulit putih di kedua negara jajahan itu. Pada tahap selanjutnya dilahirkan undang-undang yang menjamin hak alamiah dan melarang perbudakan: di Inggris pada tahun 1807 dan di Amerika pada tahun 1865.

Jaminan atas hak dasar manusia kembali dinyatakan oleh H.G. Wells dalam bukunya On the Right Man (1939-1940). Kesadaran itu disambut oleh Presiden Amerika Serikat F.D. Roosevelt (1941), yang menyerukan perlunya kebebasan berbicara, kebebasan beragama, kebebasan dari kemiskinan, dan 
kebebasan dari rasa takut atau ancaman. Implikasi dari konsep HAM adalah bahwa setiap kekuasaan harus dibatasi. Setiap orang mempunyai hak dasar yang tidak dapat diambil oleh suatu kekuasaan, setiap orang dapat menuntut kepada negara untuk menjamin dan melindungi hak dasarnya.

Akan tetapi, semua pemikiran dan dokumen ideal tersebut dilanggar oleh kesewenangan Adolf Hitler yang melakukan tindakan fasis dan diskriminatif pada tahun 1938-1945. Pelanggaran itu mendorong negara sekutu untuk memerjuangkan kembali HAM. Dorongan itu menjadi sarana untuk menumpas fasisme. Setelah Perang Dunia (PD) II dan setelah mengadili para penjahat perang di Pengadilan Nuremberg, PBB membentuk DUHAM pada tahun 1948 yang menjadi suatu konsep politik internasional. Sebagai pemenang perang, Amerika Serikat (AS) memelopori HAM untuk dimasukkan sebagai mukadimah dan pasal pertama Piagam Perserikatan Bangsa-Bangsa (PBB). Piagam itu menjadi dasar pembentukan Dewan Ekonomi dan Sosial PBB. Sebelumnya, Liga Bangsa-Bangsa (LBB) sepanjang tahun 1919-1939 telah mensponsori beberapa isu HAM, yaitu hak minoritas, hak kaum buruh, hak individu, dan masyarakat di wilayah perwalian suatu negara. Namun, isu itu dianggap belum lengkap dan tidak dapat dijalankan. Bahkan, Piagam PBB (1945) pun tidak menyebutkan HAM secara lengkap sehingga memungkinkan untuk dijalankan.

Dalam pasal 1 ayat 3 Pembukaan Piagam PBB disebutkan bahwa salah satu tujuan PBB adalah mewujudkan kerja sama internasional dalam menyelesaikan masalah internasional di bidang ekonomi, sosial, kebudayaan, atau yang bersifat kemanusiaan, HAM, dan meningkatkan serta menjunjung tinggi penghargaan atas hak asasi manusia tanpa membedakan kelas, jenis kelamin, bahasa, atau agama. Pasal itu kemudian digunakan sebagai dasar kesepakatan dalam DUHAM (1948) (Baehr 1998: 6).

Menurut Robertson, Piagam PBB merupakan perjanjian pertama yang menjadikan HAM sebagai suatu masalah yang harus mendapat perhatian global yang disebutnya mirip seperti International Bill of Rights. Namun, tugas PBB terbatas pada memajukan HAM dan bukan menjamin, sebagai masalah hukum, bagi semua warga dunia. Akibatnya, piagam itu tidak dapat diimplementasikan (Robertson 2002: 30-31).

Proses pembentukan DUHAM dimulai pada Konferensi San Fransisco (1945), yang membuat rancangan HAM untuk dimasukkan ke dalam Piagam PBB, tetapi gagal dilaksanakan. Walaupun demikian, berbagai organisasi kemasyarakatan mendesak banyak pihak. Hasilnya dibentuk komisi HAM yang anggotanya bersumber dari Dewan Ekonomi dan Sosial PBB. Tindakan awal yang dilakukan dewan tersebut adalah mendirikan komisi yang membuat draf undang-undang HAM internasional. Atas dasar itu dan berdasarkan pasal 68 Piagam PBB diputuskan pembuatan rancangan konstitusi kemanusiaan yang ditugaskan kepada Komisi HAM. Komisi itu diketuai oleh Elanor Roosevelt yang dibantu oleh profesor hukum dari Kanada, John Humprey. Mereka bekerja selama dua tahun untuk mencanangkan International Bill of Rights. Komisi itu melakukan serangkaian kegiatan dengan 
mendesak memasukannya HAM ke dalam Piagam PBB, mendesak semua negara untuk menyetujuinya sebagai suatu resolusi PBB di Sidang Umum PBB. Namun, kembali ketiga rencana itu mengalami kegagalan. Komisi atau panitia perancang draf awal HAM diwakili oleh delapan negara (AS, Sovyet, Australia, Cina, Prancis, Libanon, dan Inggris). Panitia itu bekerja dalam komisi HAM yang bersidang pada bulan Desember 1947 dan 1948 dan membicarakan draf deklarasi.

Setelah berhasil, dokumen tersebut dalam pelaksanaannya hanya berupa deklarasi tanpa kekuatan hukum. Adanya perdebatan mengenai kekuatan hukumnya, menyebabkan deklarasi itu dikembalikan dan akhirnya dibuat oleh Majelis Umum PBB yang tidak mengikat secara hukum sampai menjadi DUHAM pada tanggal 10 Desember 1948 di Paris. DUHAM ditandatangani 48 negara, kecuali delapan negara abstain dengan alasan tertentu, yaitu Uni Sovyet, Polandia, Chekoslovakia, Yugoslavia, Rumania, Hungaria, Afrika Selatan, dan Arab Saudi.

DUHAM disetujui dan diumumkan PBB lewat resolusi 271 A (III). DUHAM dianggap sebagai ideologi universal pertama di dunia. Sebelumnya, ideologi agama, politik, filsafat, ekonomi, dan kebudayaan memiliki penganut di berbagai bagian dunia. Sebaliknya, DUHAM mempersatukan perbedaan itu karena HAM berdasarkan hukum kodrat yang dianggap lebih tinggi daripada hukum negara dan HAM menekankan bahwa individu memiliki hak dasar yang dibawa sejak lahir dan tidak dapat dihapuskan.

DUHAM juga merupakan penegasan dari Piagam PBB (1945) yang bertujuan melindungi hidup, kemerdekaan, keamanan pribadi, kebebasan berpendapat, berkumpul, berkeyakinan, dan memproses pelanggaran HAM dari semua individu masyarakat dan negara. Kodifikasi DUHAM menunjukkan keinginan untuk menginternasionalkan HAM dan memanusiakan hukum internasional (Davies 1994: 10).

Akan tetapi, dalam kenyataannya upaya tersebut sering bersinggungan dengan berbagai kepentingan. DUHAM kembali tidak berdaya ketika terjadi Perang Korea (1951), berdirinya Tembok Berlin (1961), Perang Vietnam (1960 - 1975), dan intervensi AS pada beberapa negara di Amerika Latin dan Timur Tengah (2000). Dalam konteks itu, pihak Barat (AS dan sekutunya) dianggap pilih kasih hanya menindak rezim yang dianggap lemah. Namun, rezim Stalin, Khruschev, Brezhnev, dan beberapa rezim militer di Amerika Latin dibiarkan. Bahkan, AS melakukan pelanggaran HAM secara terangterangan dalam Perang Vietnam. HAM akhirnya kembali bangkit dalam bentuk konvensi dari 35 negara di Helsinki pada tahun 1975.

Terdapat dua perbedaan mengenai DUHAM dari pihak Barat dan Uni Sovyet. Pihak Barat lebih menekankan pada hak sipil dan politis, sedangkan pihak Uni Sovyet lebih menekankan pada hak ekonomi dan masyarakat. Kedua pandangan itu beralasan sebab DUHAM dalam kacamata Barat, didasari oleh kesadaran HAM yang lebih dulu berkembang di wilayah masyarakatnya. Sementara itu, hak ekonomi dan sosial merupakan bagian dari perjuangan yang dilakukan oleh Uni Soviet dalam menumbangkan rezim Tsar. Dengan kata lain, pihak Uni Soviet lebih memberikan jaminan ekonomi dan 
masyarakat yang menjadi dasar perjuangan dan legitimasi mereka daripada jaminan untuk HAM.

DUHAM merupakan suatu keinginan yang ekspansif untuk memersatukan dunia dengan membuat suatu daftar pedoman bagi semua pemerintah. Sebelumnya LBB tidak dapat berjalan karena keanggotaannya dipersulit dengan memaksakan sistem konsepsi kenegaraan model demokrasi Barat yang ingin diterapkan pada calon anggotanya. Dengan kata lain, HAM dijadikan kriteria untuk menentukan keanggotaan LBB. Ada bentuk pemaksaan dan ancaman dari negara Barat yang diterapkan kepada negara yang dianggap melanggar HAM. Ancaman itu berkenaan dengan hambatan dalam kerja sama ekonomi. Pemaksaan dan ancaman itu sebenarnya melanggar DUHAM itu sendiri dan juga melanggar hak asasi suatu negara. Akan tetapi, dalam kasus Resolusi 41/128 pada Sidang Umum PBB, ancaman dan sanksi itu disepakati oleh banyak negara anggotanya. Keputusan itu kemungkinan juga karena negara dunia ketiga mendapat ancaman dari negara maju.

Pemikiran tentang kebebasan dan kemerdekaan yang terdapat dalam pandangan Barat yang juga terdapat dalam DUHAM menjadi alat pembenaran (justifikasi) dan penilaian terhadap negara dan masyarakat yang berbeda dengan mereka. Pandangan seperti itu dianggap sebagai bagian dari konteks modernitas. Sebaliknya jika suatu masyarakat tidak melaksanakan HAM, menurut mereka akan dikategorikan sebagai negara yang masih tradisional, terkungkung oleh sistem nilai budaya dan politik statis yang tidak menghargai HAM. Sejak perjanjian Westphalia (1648) sampai PD II (Piagam PBB dan DUHAM) belum ada model yang lengkap untuk menanggulangi pelanggaran HAM di tingkat regional, apalagi internasional. Sejauh ini DUHAM dan konvensi yang lain hanya perjanjian yang tidak mengikat.

Realisasi DUHAM masih jauh dari sasaran dan harapan. Implementasi ketiga puluh pasalnya belum terpenuhi. Sampai tahun 1999 masih banyak negara yang belum meratifikasinya, termasuk AS.

\section{MulTIPERSPEKTIF DALAM HAM INTERNASIONAL}

Dalam perspektif internasional, sejatinya HAM baru dikenal setelah PD II, bahkan HAM kemudian dijadikan instrumen dalam interaksi antarnegara ketika dilakukan pengadilan penjahat perang setelah PD II di Nuremberg. HAM dikenal sebagai suatu mekanisme dalam melawan kejahatan terhadap kemanusiaan. Pasal 6 (c) Piagam Nuremberg dalam hukum Internasional menyebutkan bahwa negara dapat dikenakan hukuman oleh pengadilan mana pun atas perbuatannya mengesahkan kejahatan terhadap rakyatnya. Pengadilan dan Piagam Nuremberg telah mendorong DUHAM pada tanggal 10 Desember 1948 di Paris. Akan tetapi, dalam pelaksanaannya deklarasi itu terhambat karena perang dingin antarblok. Pada era perang tersebut dua blok yang bertikai (AS dan Soviet) sama-sama mendukung rezim militer di berbagai kawasan dunia dan DUHAM harus menyerah pada kepentingan politis (Robertson 2002: XIV - XV).

Untuk menanggulangi pelanggaran HAM dalam konteks internasional, 
telah dibentuk beberapa institusi, seperti Komisi HAM PBB dengan beberapa subkomitenya. Sampai pertengahan tahun 1990, PBB mencatat 32 perjanjian HAM. Dalam perjalanannya, konvensi, traktat, dan protokol yang sudah dihasilkan oleh PBB tidak dapat berjalan sebagaimana yang diharapkan. Pelanggaran HAM kerap kali terjadi. Atas dasar itu, sering diadakan pertemuan, lobi, dan konferensi HAM tingkat regional dan internasional. Pada tahun 1968 di Teheran, Iran, diadakan konferensi HAM yang melihat bahwa HAM makin terabaikan. Konferensi itu dilanjutkan dalam serangkaian pertemuan lainnya. Sampai akhirnya oleh Majelis Umum PBB pada tanggal 18 Desember 1992 disahkan suatu resolusi penetapan untuk segera mengadakan konferensi HAM tingkat dunia yang diselenggarakan di Wina, Austria pada tanggal 14-25 Juni 1993, yang kemudian dilanjutkan pada tahun 1997 dan tahun 2002.

Konferensi tersebut memutuskan (1) HAM bersifat universal, (2) masyarakat internasional harus memelihara HAM, (3) mempertimbangkan kemajemukan budaya, sosial, dalam pelaksanaan HAM, (4) setiap negara dituntut untuk menjamin HAM tanpa berlindung di balik relativisme, dan (5) negara maju perlu membantu negara yang sedang berkembang tanpa melanggar HAM (Effendi 1994: 79-80).

Sampai akhir abad ke-20 perjuangan HAM mengalami naik turun. Salah satu kendalanya adalah para anggota PBB yang sulit untuk dituntut meratifikasi beberapa keputusan konvensi yang ada. Padahal, ratifikasi juga menjadi bagian dari sistem negaranya. Akan tetapi, kendala lain ada perbedaan pandangan antara presiden di suatu negara dan anggota parlemennya tentang suatu konvensi yang telah ditandatanganinya.

Menurut Wilfred, HAM baru menjadi suatu yang berharga dan berperan ketika ditempatkan pada konteks proses historis dan tradisi perlawanan, yakni perlawanan terhadap rezim kolonial, rezim fasis, rezim komunis, rezim militer, rezim otoritarian-totalitarian, rezim korporat dan rezim negara pembangunan. Jika konteks dan kondisi tersebut melemah, proses penegakan HAM pun menjadi melemah.

HAM dalam sejarah selalu bersejajar dengan agama. Gagasan dasar yang dapat menghubungkan HAM dengan beberapa agama adalah martabat manusia. Prinsip etis dasar HAM dan agama adalah sama, yaitu bahwa martabat kemanusiaan tidak dapat diambil oleh orang lain. Ketika pihak yang dominan dan mempunyai kekuasaan hegemoni memaksa lainnya, HAM kemudian cenderung menuju pada pemaksaan. Tindakan itu seakanakan ingin memperadabkan pihak lain yang masih hidup dalam kondisi pratradisional, persis seperti tugas para misionaris imperialistik pada zaman kolonial Barat (Biefeldt 2001: 31).

Hal ini menjadi ekses negatif yang tidak dapat dihindari sebab HAM juga dapat menjadi komoditas, walaupun awalnya sangat ideal untuk menjunjung martabat kemanusiaan. Namun, setelah terinflitrasi dengan unsur politis, ekonomis, sosial, dan budaya, unsur idealnya terlupakan. Bahkan, HAM dijadikan legitimasi bagi negara kuat untuk mengadakan intervensi atas dasar 
kemanusiaan. Pada tahun 1980--1990, HAM sering dijadikan alat penekan oleh politik luar negeri dari negara Eropa Barat dan Amerika Serikat. Beberapa negara yang dianggap melanggar HAM ditekan dengan berbagai cara, seperti embargo, pembatasan kuota, kritik langsung, sampai invasi militer jika diperlukan. HAM menjadi senjata moral mereka dalam berinteraksi dengan negara di luar Eropa Barat dan Amerika Serikat.

Konsepsi ini didasarkan pada pemikiran liberalisme dan misi moral yang terdapat pada bangsa Amerika Serikat dan Eropa Barat. Dalam konsep ini terkandung bahwa HAM adalah hak yang melekat pada seseorang sejak mereka lahir. Siapa pun tidak dibenarkan untuk menghambat atau mencabut hak orang lain. Setiap orang harus menghormati hak orang lain demi kesadaran dan peningkatan harkat dan martabat kemanusiaan, tanpa melihat perbedaan fisik, ras, agama, gender, masyarakat, ekonomi, politik, dan budaya (Hartz 1955: 2-5).

Pada era Presiden Jimmy Carter (1977-1981), HAM menjadi kebijakan politik luar negerinya dalam mengadakan hubungan dengan negara mana pun. Aspek HAM menjadi perhatian utama yang ditanyakan dan ditawarkan oleh pihak AS. Dengan demikian, HAM dan demokrasi menjadi opini dan wacana dunia, bahkan menjadi proyek global dari negara Barat dalam menjalin hubungan dengan negara lain, termasuk Indonesia. HAM menjadi senjata moral mereka untuk menekan kebijakan dalam negeri yang berhubungan dengannya.

\section{DuA PANDANGAN DALAm HAM INTERNASIONAL}

Terdapat dua pandangan dalam perspektif HAM internasional. Pertama pandangan kubu radical cultural universalism yang dianggap diwakili oleh negara Barat. Kedua, kubu radical cultural relativism atau yang juga dikenal sebagai kubu partikularis, yang diwakili oleh negara dunia ketiga. Kubu pertama menganggap bahwa individulah yang menentukan haknya, juga hak masyarakat dan negara berdasarkan konvensi. Pihak lain berpandangan bahwa kebudayaan merupakan pedoman yang mengatur hak masyarakatnya. Menurut kubu kedua, keragaman budaya adalah suatu hak pilihan untuk berbeda dengan masyarakat dan budaya lain (Howard 2000; Koch 2001).

Kekuasaan negara yang meliputi politik budaya setempat menjadi acuan yang menentukan hak individu, masyarakat, dan negara itu sendiri. HAM, menurut kubu kedua tersebut, tidak dapat diwujudkan secara universal di tiap negara dan pemerintah karena adanya kendala keyakinan pandangan tersebut. Jadi, kedua pandangan itu tidak pernah bertemu karena berbeda dalam cara melihat hak individu, masyarakat, dan negara masing-masing (Donnelly 1989: 122; Rentein 1990).

Donnelly dan Rhoda menekankan bahwa individu dalam masyarakat modern sangat membutuhkan perangkat HAM karena HAM merupakan bentuk kesadaran modernis. Akan tetapi, pada zaman modern, ternyata konsep relativisme budaya dan partikularisme menolak adanya kesadaran 
individu yang berkaitan dengan HAM. Padahal, sebagai negara modern perangkat kontrol merupakan salah satu bagian dari kesadaran modern itu sendiri. Jadi, banyak negara yang baru melepaskan diri dari kolonialisme atau negara yang termasuk rezim militer dan sosialis, seperti di Amerika Selatan dan Eropa Timur, menafikan kesadaran dan keberadaan individu yang mempunyai hak untuk mengontrol dan berpartisipasi dalam politik pemerintahan. Barometer itu dapat dilihat dari apakah hak politik individu atau masyarakat dikebiri oleh pemerintah setempat. Jika hak itu diintervensi dan dihambat, berarti ada pelanggaran HAM, termasuk hak warga negara yang masih didiskriminasikan sebagai bekas tahanan politis. Ditekankan oleh Donnelly dan Rhoda bahwa kekuasaan sangat jarang memerhatikan HAM, bahkan tidak ada sistem pemerintahan, rezim politis dan pemikiran yang berani menjamin HAM. HAM akan selalu diguncang oleh kekuatan negara. Salah satu bentuk tugas dan peran lembaga HAM adalah mengontrol negara dalam menjamin HAM dalam masyarakatnya (Donnelly dan Rhoda 1989: $22-23)$.

Relativisme budaya menganggap bahwa tidak ada satu budaya pun, adat istiadat, dan keyakinan yang mendominasi budaya lain dalam pengertian moral. Mereka menganggap bahwa HAM tidak relevan untuk budaya yang tidak menganut adat istiadat karena berasal dari keyakinan dan nilai Barat. Relativisme budaya merupakan suatu pandangan yang memersepsikan gejala sosial budaya dari perspektif para penganut budaya yang bersangkutan. Dengan kata lain, itu menjadi suatu pandangan dalam pemertahanan budaya dari gempuran luar yang dominan (Howard 2000: 82-83).

Adamantia Pollis dan Peter Schwab, tokoh relativis budaya, menolak HAM universal sebab hak sipil dan politis tidak bermakna bagi sebagian masyarakat di luar dunia Barat. Menurut mereka, alasan perjuangan gerakan HAM universal, adalah hak tersebut tidak dihargai dan diterima sebagai prinsip universal. Bahwa setiap masyarakat pada dasarnya sudah memiliki kerangka acuan tentang hak mereka yang terdapat dalam tradisi dan kebudayaannya. Dengan demikian dalam masyarakat yang berbeda terdapat konsepsi HAM yang berbeda pula. Akibatnya semua sistem keadilan sosial, moralitas, dan martabat manusia yang terdapat dalam kebudayaan tertentu dapat dipandang sebagai sistem HAM.

Kritik relativisme terhadap HAM universalisme sama dengan kritik dan pandangannya terhadap modernisme, liberalisme, individualisme, kapitalisme, dan imperialisme Barat. Sementara itu, kritik kaum universalisme terhadap kaum relativisme yang cenderung berada di belakang budaya, menganggap pandangan mereka itu represif, diskriminatif, tidak bebas, ekslusif, dan homogen. Menurut pandangan universalisme, jika suatu perubahan cenderung berproses dengan sehat memungkinkan seseorang dapat memilih dan menjadi dinamik. Masyarakat yang berubah menunjukkan kemajuan. Sebaliknya, masyarakat tradisional adalah masyarakat yang statis (Rentelu, Pollis, dan Schwab dalam Howard, 2000: 86 -88).

Dari dua pandangan tersebut dapat dilihat bahwa kubu relativisme 
menggunakan latar sejarah dan kebudayaan untuk dijadikan dasar justifikasi dan pembenaran sepihak dari negara yang sebenarnya menolak beberapa ketentuan yang disepakati. Dengan kata lain, mereka selalu berlindung di balik kerelatifan budayanya masing-masing. Di samping itu, HAM seakan dipaksa menjadi kebudayaan global yang harus berhadapan dengan kebudayaan lokal, akibatnya sering terjadi konflik kepentingan. Jika kebudayaan lokal tersebut didominasi oleh suatu rezim baik suatu etnik, ekonomi, budaya, dan militer, HAM sebagai kebudayaan global akan sulit untuk dioperasionalkan.

Diketahui bahwa banyak negara belum meratifikasi berbagai konvenan yang telah disepakati bersama mengenai berbagai aspek penjagaan terhadap HAM. Ditambah lagi dengan munculnya sikap kontradiktif dalam penyelenggaraan HAM di dunia ketiga. Mereka menganggap bahwa konsepsi kemanusiaan dan kemasyarakatan yang terdapat dalam berbagai konvensi HAM bersifat relatif. Mereka menganggap bahwa konsepsi itu memerlihatkan pandangan dominasi negara Barat sehingga tidak dapat diterapkan di berbagai negara yang berbeda kebudayaannya.

HAM, dalam perkembangannya, telah melewati tiga periode, yaitu masa kesadaran (1948-1950-an), masa pertumbuhan (1960-1980), masa penegakan (1990-2000). Pihak lain melihat perkembangan HAM dalam babakan generasi. Generasi Pertama muncul pada DUHAM (1948), generasi kedua muncul ketika lahir Konvenan Ekonomi, Sosial, dan Budaya pada tahun 1966. Sintesis antara HAM generasi pertama dan kedua terdapat dalam HAM generasi ketiga yang menekankan aspek HAM dalam pembangunan (the rights to development), khususnya HAM untuk negara dunia ketiga atau negara yang sedang membangun. Gagasan HAM generasi ketiga dimunculkan pada konferensi HAM Afrika yang menghasilkan Piagam Afrika pada tahun 1980. Dalam konferensi itu, muncul isu bahwa kemiskinan merupakan suatu kewajiban yang mendasar untuk diperjuangkan oleh LSM Developmentalis. Selanjutnya, muncul HAM generasi keempat pada tahun 1983 yang disponsori oleh negara di kawasan Asia yang melahirkan Declaration of the Basic Duties of Asia People. Deklarasi itu menekankan peranan pemerintah untuk memenuhi tuntutan HAM dari rakyatnya sebab HAM sudah menjadi urusan negara.

PBB tidak secara struktural dan psikologis dirancang untuk mewujudkan janji DUHAM, tetapi hanya merancang institusi yang independen dari politik internalnya. Organ PBB dapat membuat keputusan yang mengikat bagi anggotanya, namun tidak mungkin berjalan jika tidak ada dukungan kekuatan dari dewan keamanan. Kelemahan fungsi komisi HAM di PBB, menurut Roberston (2002: xix - xx) adalah karena tunduk pada kedaulatan anggotanya. Seharusnya sistem perjanjian regional dan pengadilan HAM internasional dapat dipahami dan dihargai, tetapi pada kenyataannya tidak.

Maraknya pelanggaran HAM secara tidak langsung telah mendorong gerakan HAM untuk muncul ke permukaan dalam mengontrol suatu rezim. Masalah HAM berkembang menjadi isu politik internasional dan mendorong munculnya banyak lembaga HAM yang jumlahnya melebihi lembaga di bidang lain. Pelanggaran HAM bukan hanya terjadi pada masa perang, pada 
saat damai pun ternyata tidak berkurang. Pelanggaran HAM yang dilakukan oleh suatu rezim pada masa damai lebih berstruktur dan berproses lebih lama. Bahkan, tidak tertutup kemungkinan pelanggaran HAM juga dilakukan oleh negara maju. Dengan demikian, pelanggaran HAM tidak hanya dipengaruhi oleh faktor politis dan budaya, tetapi juga sosial dan ekonomi.

Menanggapi fenomena tersebut, beberapa lembaga HAM yang terdapat di dunia saling bekerja sama, contohnya Amnesty International, Komisi Pakar Hukum Internasional, International Helsinki Federation for Human Rights, American Watch, Africa Watch, Asia Watch, dan Liga Internasional untuk HAM. Amnesty International hanya bertugas untuk membebaskan semua tahanan politis, antikekerasan, menghapus hukuman mati, penyiksaan, dan perlakuan kejam, serta menghentikan penghukuman tanpa proses. Senjata dan tujuan dari lembaga kemanusiaan, seperti Amnesty International adalah untuk menggugah rasa malu dan bersalah suatu negara atau suatu rezim (Baehr 1998: 58; Amnesty International Report, Russian Event 1993 - 2000).

Konsep HAM, pada hakikatnya merupakan konsep tertib dunia. HAM pada pelaksanaannya menjadi persoalan hukum dan harus diatur sesuai dengan ketentuan hukum. Oleh sebab itu, landasan hukum yang memuat dan mengatur HAM harus tetap dijaga oleh pemerintah dan masyarakatnya sendiri. HAM dengan negara hukum merupakan satu kesatuan. Alasannya salah satu tujuan pembentukan negara hukum adalah melindungi HAM. Sebaliknya, keberadaan HAM akan memerlihatkan bagaimana realisasi dari tatanan hukum itu sendiri. Bagaimanapun tanpa sanksi hukum, HAM tidak akan berarti dan tidak banyak berpengaruh pada perbaikan institusi HAM itu sendiri. Oleh sebab itu, HAM harus diberi bobot hukum sehingga menjadi landasan legalitas untuk bertindak. Akan tetapi, masalah itu masih terus diperdebatkan dan masih dipertanyakan apakah DUHAM, Kesepakatan Helsinki (1975), dan Kesepakatan Wina (1991) dapat dijadikan landasan untuk bertindak. Sementara itu, isi ketentuan hanya bertaraf imbauan dan bukan merupakan konstitusi internasional. Kalaupun ada sanksi, itu pun di luar ketentuan yang ada. Sanksi itu muncul karena adanya kepentingan dari negara kapitalistik. Sanksi dan intervensi pun banyak yang tidak mengubah perbaikan HAM di suatu negara.

Namun, menurut Kjeldsen, Mukadimah Pasal 55 dan 56 bersama Pasal 41 dan 42 Piagam PBB dapat dijadikan legitimasi untuk bertindak masuk ke suatu negara dengan atau tanpa intervensi militer demi penegakan HAM. Hal itu karena disintegrasi dan instabilitas di suatu negara cenderung merusak tatanan HAM dan menjadi ancaman bagi perbaikan dan penegakan HAM dan sistem demokrasi (Hastrup 2001: 40-44).

Apakah hubungan demokrasi dengan HAM? HAM dan demokrasi merupakan satu kesatuan yang saling mendukung dan tidak dapat dipisahkan karena demokrasi adalah wadah untuk menghargai martabat kemanusiaan. Demokrasi politik mencakup hak sipil dan politis, seperti kebebasan berpendapat, kebebasan pers, kebebasan berorganisasi, dan hak untuk berpartisipasi dalam politik. Suatu negara demokratis seharusnya 
memerjuangkan dan menjaga hak-hak itu. Menurut laporan dari UNDP dan Freedom House, sebenarnya terdapat empat puluh jenis hak dan kebebasan yang menjadi ukuran kuantitatif suatu negara disebut demokrasi. Jadi suatu negara dapat disebut sebagai negara demokrasi yang baik, kurang baik, tersendat, terbatas, semu, dan beku, bergantung pada cara suatu negara menghormati ke-40 jenis HAM itu.

Bahkan, negara Barat melihat bahwa kondisi HAM di suatu negara dapat dijadikan ukuran bagi kemajuan dan perkembangan demokrasi suatu masyarakat dan negara. Menurut anggapan mereka kunci pembangunan dan kemajuan tidak terletak pada negara, tetapi pada kebebasan individu dan masyarakat sipil itu sendiri.

\section{Kritik HAM sebagai Alasan Moral}

Kritik terhadap HAM tertuju khususnya pada adanya kepentingan terselubung (hidden agenda) dari beberapa negara kapitalis yang mensponsori kegiatan Ornop HAM. Para pengkritik mempertanyakan mengapa HAM dapat ditetapkan secara homosentris oleh seorang manusia atau ditentukan oleh negara yang berdaulat. Mereka menganggap HAM hendak ditetapkan sebagai mata uang moral untuk semua kota dan desa di segenap penjuru dunia (Gostavo \& Prakash 2001: 53).

Menurut pandangan liberal, pada prinsipnya setiap individu berhak menuntut hak asasi otonominya kepada negara dan masyarakat tanpa membedakan status kedudukan dan kebudayaan. Sebaliknya, golongan tradisional dan komunitarian berpendapat bahwa liberalisme menghancurkan hubungan antarbudaya, kerabat, komunitas, dan mencabut hak anggota kelompok. Jadi, sebenarnya kritik terhadap HAM juga merupakan kritik terhadap modernitas, liberalisme, dan dampak pasar kapitalis (Howard 2000: 39, 65-69).

Para pengkritik HAM disebut sebagai kelompok tesis Central Park yang berlogika bahwa filsafat HAM bersifat individualis dan antikomunitarian dan kemajemukan. HAM adalah konsep Barat dan Amerika Serikat yang memperlihatkan keserakahan neoliberalisme. HAM di Amerika secara tidak langsung telah membiarkan kejahatan terhadap manusia lain tanpa ada sangkalan dari pihak Ornop HAM sendiri. Menurut mereka implikasi liberalisme banyak yang justru melanggar HAM (Howard 2000: 37).

Pada kenyataannya, HAM telah dialihkan menjadi perangkat yang lebih banyak melindungi kepentingan mereka yang mempunyai kekuasaan dan sebaliknya kurang melindungi mereka yang membutuhkan. Bahwa proklamasi modern HAM dimunculkan oleh tradisi liberal yang pada sejarah kelahirannya berpusat pada klaim hak sipil dan politis yang tidak boleh dihambat dalam pelaksanaannya oleh siapa pun. Konsep itu menjadi dasar bagi mereka untuk diimplementasikan (Wilfred 2001: 110-112).

Pelanggaran terbesar HAM, dipandang dari segi global, adalah ekonomi dunia itu sendiri. Pasar bebas telah menjadikan negara miskin membayar kembali lebih daripada apa yang telah diterimanya dalam bentuk utang 
melalui agennya, International Monetary Fund (IMF). Mereka menekan pemerintah dunia ketiga agar mengikuti kebijakan ekonomi dunia yang berarti kemiskinan dan pemiskinan. Bahkan juga kematian bagi anggota masyarakat dunia yang paling miskin.

Kapitalisme lintas negara dengan perdagangan pasar bebasnya, dalam kenyataanya, telah merembes sekaligus mencakup seluruh kehidupan manusia. Sesungguhnya, kapitalisme menjadi pelanggar HAM yang tersembunyi. Saat ini kerangka HAM didorong untuk memerangi pelanggaran yang dilakukan oleh negara dan korporat. Strategi dan mekanisme diciptakan terutama untuk memonitor fungsi negara dan menghormati HAM. Gerak kapitalisme dianggap menjadi Leviathan Baru yang sangat sulit untuk dikontrol.

Para pengkritik perpandangan bahwa sangat kontradiktif jika seseorang dapat menggabungkan antara kepentingan pasar dan HAM. Alasannya struktur dan fungsi pasar adalah antitesis bagi HAM, keduanya jelas bertentangan. Dari sudut pandang perekonomian neoliberalisme dan pasar kapitalis, advokasi HAM akan dirasakan sebagai tantangan dan kendala bagi keamanan sistem dan struktur pasar. Hal itu terjadi karena yang berlaku adalah tidak ada satu pihak pun yang dapat secara sungguh-sungguh mengabdikan dirinya pada pasar sekaligus kepada HAM. Jika ada penampilan yang menunjukkan kesesuaian antara HAM dan pasar, itu merupakan tanda kemunafikan yang nyata. Itulah yang sering dinyatakan oleh banyak bangsa di belahan Selatan ketika melihat bangsa di Utara mempromosikan HAM secara gencar. Apa yang disebut sebagai structural adjusment program, yang dipaksakan kepada bangsa lain, sesungguhnya adalah cara untuk mempertahankan sistem perekonomian neoliberalisme dengan mengorbankan kaum miskin dan hak yang mereka miliki. Mereka mempertanyakan bagaimana mungkin berjalan seiring dengan mereka yang tidak memiliki pandangan HAM (Wilfred 2001: 115-116).

Salah satu faktor dasar dari perekonomian model neoliberalisme adalah kekuatan kompetisi. Segala sesuatu yang didasarkan pada prinsip kesetaraan bertentangan dengan dinamika perekonomian semacam itu sebab sistem ekonomi kapitalis justru didasarkan atas prinsip ketaksetaraan. Faktor itu dibutuhkan oleh sistem demi keselamatan dan keberlanjutan. Sebaliknya, HAM ditegakkan di atas prinsip kesetaraan. Jadi, jelas bahwa HAM dan kapitalisme pasar merupakan dua kubu yang berbeda dan bertentangan. Apalagi kapitalisme pasar selalu menghindari wilayah yang dapat mengakibatkan risiko bagi keuntungannya.

Sistem ekonomi neoliberalis dan pasar terbuka global didasarkan pada model pembangunan yang homogen. Model itu mengikat kerja sama antara para pemodal dan negara model patriarkial di belahan Asia. Bahkan, proyek model pembangunan homogen itu tidak dapat berdampingan dengan komitmen sekaligus kepada kemiskinan dan HAM sebab proyek tersebut berisi kekerasan dan agresi terhadap kemanusiaan. Proyek model itu oleh Noam Chomsky (Wilfred 2001: 118) disebut sebagai TNA-Syndrome (There is No Alternative Syndrome). 
Pemberdayaan HAM dan demokrasi dianggap sebagai proyek demokrasi neoliberal dari negara kapitalis Barat yang didasarkan pada pengembangan privatisasi, denasionalisasi, dan deregulasi yang berusaha mengambil alih sebagian peran negara yang telah berlebihan mengooptasi masyarakatnya. Tujuannya adalah tersedia pasar terbuka yang dapat memberikan akses kepada pihak luar untuk menanamkan modalnya dan menyalurkan produk industrinya ke negara yang bersangkutan. Akibatnya Wallerstein, Munck, Spar, dan Salmi mencurigai bahwa redemokrasi dalam negara Eropa Timur (Rusia) adalah mekanisme penyesuaian bagi keterlibatan yang semakin dalam serta partisipasi yang semakin meluas di dalam kerangka sistem kapitalis internasional (Hikam 1999: 40).

Berkaitan dengan itu, pemerintah Amerika Serikat dan Uni Eropa dicurigai menjadi penyandang dana terbesar untuk lembaga demokrasi dan HAM baik di tingkat lokal, regional, maupun internasional. Pihak Amerika Serikat dan Uni Eropa menggunakan mereka sebagai subkontraktor atau agen dalam program bantuannya. Bantuan dana resmi kepada mereka dapat menjadi pedang bermata dua. Alasannya USAID cenderung untuk memengaruhi kelompok jaringan tersebut dan sekaligus mengarahkan tujuan mereka agar sesuai dengan kepentingan politik luar negerinya (Clark 1995: 52; Over 1999: 45-55).

Bagi bangsa di Selatan, dunia ketiga, dan negara pascakomunis, isu HAM pada zaman modern dihubungkan dengan perjuangan mereka melawan kekuasaan rezim kolonial, rezim militer, dan rezim otoritarian-totalitariankomunis yang merupakan bentuk nyata untuk mengklaim hak mereka yang sah. Namun, dalam prosesnya kebanyakan, negara kembali melakukan pelanggaran HAM atas rakyatnya sendiri, seperti rezim terdahulu.

Berhubungan dengan globalisasi, HAM tidak lagi menjadi masalah nasional, tetapi sudah menjadi masalah internasional. Dalam konteks itulah akan selalu muncul perbedaan pandangan dalam menginterpretasi pelanggaran HAM yang terjadi di suatu negara atau menginterpretasi intervensi satu negara ke negara lain. Masyarakat internasional, bahkan komisi HAM PBB sendiri, hampir ragu untuk mengatakan bahwa intervensi Israel ke wilayah Libanon adalah pelanggaran HAM atau intervensi militer AS ke Afganistan adalah pelanggaran kemanusiaan atau penjara Gulak baru yang dibangun AS di Guantanamo Kuba, adalah pelanggaran HAM. Semua kasus tersebut menjadi wajar ketika perspektif yang lebih kuat membenarkan tindakannya. Dengan demikian, masalah HAM akan selalu dipengaruhi oleh berbagai kepentingan, baik nasional, regional, maupun internasional. 


\section{DAFTAR ACUAN}

Baehr, Peter R. (1998). Hak-Hak Asasi Manusia dalam Politik Luar Negeri (penerjemah: Somardi). Jakarta: Yayasan Obor Indonesia.

Clark, John. (1995). NGO dan Pembangunan Demokrasi. (penerjemah: Godril D. Yuwono). Yogyakarta: Tiara Wacana.

Crawshaw, Ralph dan Leif Holmstrom (eds). (2001). Essential Texts on Human Rights for The Police. The Hague; Kluwer Law University

Davidson, Scoot. (1993). Human Rights. Buckingham: Open University Press.

Davies, Peter. (1994). Hak-Hak Asasi Manusia: Sebuah Bunga Rampai. (Penerjemah: A. Rahman Zainudin). Jakarta: Yayasan Obor Indonesia.

Donnelly, Jack. (1989). Universal Human Rights in Theory and Practice. London: Cornell University Press.

(1993). International Human Rights. Boulder: Westview Press.

Effendi, Masyhur. A. (1994). Hak Asasi Manusia: dalam Hukum Nasional dan Internasional. Jakarta: Ghalia Indonesia.

Elisabeth, Ida Koch. (2001). "Legal Pluralis in the Human Rights Universe", (Hastrup, ed). Human Rights on Common Grounds: The Quest for Universality. The Hague: Kluwer Law University.

Gostavo, Esteva dan Prakash, Madhusuri. (2001). “Hak Asasi Manusia Kuda Troya Rekolonisiasi", dalam Jurnal Wacana. Edisi 8 Tahun II. Yogyakarta; INSIST Press.

Hartz, Louis. (1955). The Liberal Tradition in American. New York: Horcourt Brace and World. Inc.

Hastrup, Kirsten, (ed). (2001). Human Rights on Common Ground: Quest for Universality. The Hague: Kluwer Law International.

Hikam, Muhammad. (1999). Demokrasi dan Civil Society. Jakarta: LP3ES.

Howard, Rhoda E. (2000). HAM: Penjelajahan Dalih Relativisme Budaya. (penerjemah: N. Katjasungkana). Jakarta: Grafiti.

Lawson, Edward. (1996). Encyclopedia of Human Rights. Taylor and Francis.

Munck, Ronaldo. (2002). "Globalization and Democracy: A New Great Tranformation?", The Annals. 581. May. London: Sage Publication.

Nickel, James W. (1996). Hak Asasi Manusia: Refleksi Filosofis atas Deklarasi Universal Hak Asasi Manusia (terjemahan). Jakarta; PT Gramedia.

Over, William. (1999). Human Rights in the International Public Sphere: Civil Discourse for the $21^{\text {st }}$ Century. Stamford: St John`s University.

Rentein, AD. (1990). International Human Rights: Universalism Versus Relativism. New Bury Park: Sage.

Robertson, Geoffrey QC. (2002). Kejahatan terhadap Kemanusiaan: Perjuangan untuk Mewujudkan Keadilan Global. (terjemahan). Jakarta: Komnas HAM Indonesia.

Salmi, Jamil. (2003). Kekerasan dan Kapitalisme. Yogyakarta: Pustaka Jaya.

Spar, Debora L. (1997). “The Spotlight and the Bottom Line: How Multinational Export Human Rights", Foreign Affair, Vol 77, No 2. Maret/April.

Wilfred, Felix. (2001). "Hak Asasi Manusia ataukah Hak-Hak Asasi Kaum Korban”, dalam Jurnal Wacana. Edisi 8 tahun II. Yogyakarta: INSIST Press. 